\title{
Handling, confinement and anaesthetic exposure induces changes in the blood and tissue immune characteristics of gilthead sea bream
}

\author{
L. Cubero, A. Molinero* \\ Departamento de Biologia Celular y Fisiología, Facultad de Ciencias, Universidad Autónoma de Barcelona, \\ E-08193 Bellaterra, Barcelona, Spain
}

\begin{abstract}
The gilthead sea bream Sparus aurata is a species of great interest for aquaculture, and in the last few years its culture has increased in the Mediterranean. This study was carried out to elucidate the mechanisms underlying the immunological response of fish after handling and confinement, procedures commonly associated with fish transport, as well as to determine the putative protective role of an anaesthetic (tricaine methanosulphonate) during confinement. Handling produces changes not only in circulating blood cells but also in the immunological cell populations of the thymus, spleen and pronephros. A stronger response in immunological cells was obtained when handling was followed by confinement. Circulating white blood cells returned to normal approximately $48 \mathrm{~h}$ after the onset of stress, whereas immunological tissue cells recovered later. The presence of an anaesthetic partially prevented the circulatory response, suggesting that the immunological response was less and supporting therefore the belief that the anaesthetic plays a protective role. However, it worsened the effect of handling plus confinement on haematopoietic organs, indicating that examining immunological cells in circulation only can lead to a false conclusion. Our results suggest that fish are not completely recovered until at least $144 \mathrm{~h}(6 \mathrm{~d})$ after handling and transport, when cellular recovery in immunological organs occurs
\end{abstract}

KEY WORDS: Handling Confinement Gilthead sea bream - Anaesthetic (tricaine methanosulphonate) $\cdot$ Thymus $\cdot$ Spleen $\cdot$ Pronephros

\section{INTRODUCTION}

In aquaculture, management procedures such as transport and handling are inevitable. However, these procedures produce disturbances which can elicit a stress response (Pickering 1981), leading to decreased fish performance and survival. Handling and transport of fish are known to produce alterations of the peripheral leucocyte distribution, such as heterophilia and lymphocytopenia (Anderson et al. 1982, Peters \& Schwarzer 1985, Ellsaesser \& Clem 1986, Maule \& Schreck 1990, Ainsworth et al. 1991), as well as increased susceptibility to diseases (Wedemeyer 1970 , Wedemeyer \& McLeay 1981, Pickering \& Pottinger

\footnotetext{
-Addressee for correspondence. E-mail: a.molinero@cc.uab.es
}

1985, Maule et al. 1989). These changes appear to be due mainly to stress-induced increases in circulating corticosteroids, especially cortisol, which can alter different immune functions (Slicher 1961, Maule et al. 1987, Pickering et al. 1989). However, most studies on the effects of stress and corticosteroids on the immune system of fish have focused on the haematological and immunological features of peripheral blood, and their putative effects on the cell populations of the immunological organs remain largely unknown. Changes in immune cell distribution within such organs rather than in the blood, and the duration of these changes, could have a more important effect on the health of fish in culture than previously believed.

The gilthead sea bream Sparus aurata is a teleost species with a great potential for commercial aquaculture and in the last few years many Mediterranean 
countries have increased its production. The main objective of this study was to determine the magnitude of the immunosuppression produced by the common aquaculture procedures, handling and confinement. To this end, we studied the commonly used circulating white blood cell composition, and also the distribution of immunological cells in the major teleost lymphomyeloid organs, i.e. the thymus, spleen and pronephros (head kidney). Additionally, we evaluated the putative protection offered by anaesthetizing the animals with tricaine methanosulphonate during confinement at a density similar to that used for transportation.

\section{MATERIAL AND METHODS}

Animals. Eight hundred gilthead sea bream Sparus aurata weighing 160 to $180 \mathrm{~g}$ were obtained from a commercial fish farm (CUPIMAR, Cadiz, Spain) in November 1993. The fish were initially kept in large $9000 \mathrm{l}$ indoor tanks (acclimation tanks), each supplied with a constant flow of recirculated seawater, and were fed twice daily on commercial pellets ( $1 \%$ of body weight). Water temperature ranged between 14 and $17^{\circ} \mathrm{C}$. After $14 \mathrm{wk}, 112$ bream were randomly distributed into $275 \mathrm{l}$ tanks and acclimated for $20 \mathrm{~d}$.

Experimental treatments. After the acclimation period, the fish were divided into 4 experimental groups: Control (C), handling (M), handling plus confinement $(\mathrm{T})$ and handling plus confinement with the addition of the anaesthetic tricaine methanosulphonate (A). The detailed procedure was as follows:

Control fish (C): Fish were maintained at a fish density of $7 \mathrm{~kg} \mathrm{~m}^{-3}$ and supplied with a constant flow of fresh seawater $\left(1 \mathrm{l} \mathrm{min}^{-1}\right)$. Fish were captured at 24,48 , 96 and $144 \mathrm{~h}$ for blood and tissue analysis ( $\mathrm{n}=7$ at each sampling time). To avoid the possible collateral stress effect on the remaining fish caused by the capture process (Molinero et al. 1997), the fish were captured from 4 independent tanks, one for each experimental period.

Handling fish (M): Fish were maintained in 4 independent tanks under the same conditions as those of (C). At time 0 , the fish were removed from the tank and their length and weight measured immediately (within 1 min). The fish were then returned to the tanks and not disturbed until capture for sampling at 24, 48, 96 and 144 h. ( $n=7)$, using a different tank each time.

Handling plus confinement fish (T): Fish were handled as those for (M); in addition, they were placed in separate tanks in which the water supply was interrupted and were subjected to a short period of confinement by increasing the stocking density to $20 \mathrm{~kg} \mathrm{~m}^{-3}$ for $2 \mathrm{~h}$. The fish were then returned to their original tanks, to the control fish density and conditions, and remained undisturbed until captured for sampling in the manner described above.

Handling plus confinement fish with anaesthetic (A): Fish were treated as those for (T) but, in addition, anaesthetic was added to the confinement tanks at a concentration of $25 \mathrm{mg} \mathrm{l}^{-1}$ (Molinero \& Gonzalez 1995).

Blood immunological cells staining and counting. Blood samples were taken from the caudal vessels of all fish with a heparinized syringe. The whole procedure lasted less than 3 to 4 min per group. Blood smears were made for specific blood cell counts, and stained using a modified Wright-Giemsa staining technique (Diagnostic Grifols S.A., Barcelona, Spain), which shortens the staining time from the usual 3 to $5 \mathrm{~min}$ per sample to $15 \mathrm{~s}$. This stain makes nuclei appear violet while the color of the cytoplasm varies according to the cell type.

Cell counting was carried out along the widh of a slide at the end of each smear, with an average of 100 leucocytes and 150 thrombocytes being counted along one $80 \mu \mathrm{m}$ wide column under a Nikon microscope at $1000 \times$ using a E11A-21mm/1mm Index Grid (Graticules Ltd). Results are expressed as the relative percentage of each cell type following Ellsaesser \& Clem (1986).

Tissue immunological cells staining and counting. After blood sample extraction, fish were killed by decapitation and the thymus, spleen and pronephros were removed and placed in Bouin's fluid for 18 to $24 \mathrm{~h}$ to fix the tissue. After fixation, the immune organs were dehydrated and embedded in paraffin in an Autotechnicon Duo 2A and then $6 \mu \mathrm{m}$ sections were cut using a microtome. Sections were stained with Wright's Haematoxylin and Eosin. Cell count criteria were based on the color of the cytoplasm, nuclear shape and size, and chromatin distribution within the nucleus (Zuasti \& Ferrer 1988, 1989). Cell counting was carried out in the cortex of the thymus and spleen, a few micrometres beneath the outer cell layer of the pronephros, and in peripheral accumulations of immune tissue among nephric tubules and glomeruli. Cells were counted in a $80 \times 80 \mu \mathrm{m}$ square at $1000 \times$ using a Nikon light microscope with the aid of an E $11 \mathrm{~A}-21 \mathrm{~mm} / 1 \mathrm{~mm}$ Index Grid. In addition, the number of melanomacrophage centres per $800 \times 800 \mu \mathrm{m}$ square at $100 \times$ was determined in the spleen and pronephros. For the thymus a mitotic index per 100 cells was calculated after counting the number of mitotic cells in a $200 \times 200 \mu \mathrm{m}$ square $(500$ to 800 cells $)$. Despite these criteria many cells remained unidentified or were considered to be immature stages of leucocytes, thrombocytes or erythrocytes.

Statistical analysis. Data obtained were subjected to logarithmic transformation and to analysis of variance, once homogeneity of variances had been ensured 
(Cochran's test). Duncan's test $(\mathrm{p}<0.05$ ) was performed to identify the significant differences between groups. The nonparametric Mann-Whitney $U$-test was performed when variances were not homogeneous. For simplicity, all data in the text and figures are given as the arithmetic mean $\pm \mathrm{SD}$

\section{RESULTS}

\section{Circulating leucocytes}

Table 1 shows that the 3 types of treatments produced specific changes in circulating white blood cells. Handling and handling plus confinement had the greatest effect on the percentage of heterophils and acidophils, respectively (up to $96 \mathrm{~h}$ ). The presence of an andesthetic worsened the effect of handling plus confinement on the basophilic percentage, and in addition, delayed the acidophilic and basophilic response. The anaesthetic reversed the transient lymphocytopenia caused by handling plus confinement (Table 1). Lymphocyte response in the anaesthetized group was similar to that of the control group fish.

\section{Lymphomyeloid organs}

\section{Thymus}

Whereas handling did not significantly affect the mitotic index, confinement with or without an anaesthetic increased it significantly (Fig. 1). The lymphocytopenia noted in all treated fish at $24 \mathrm{~h}$, which was

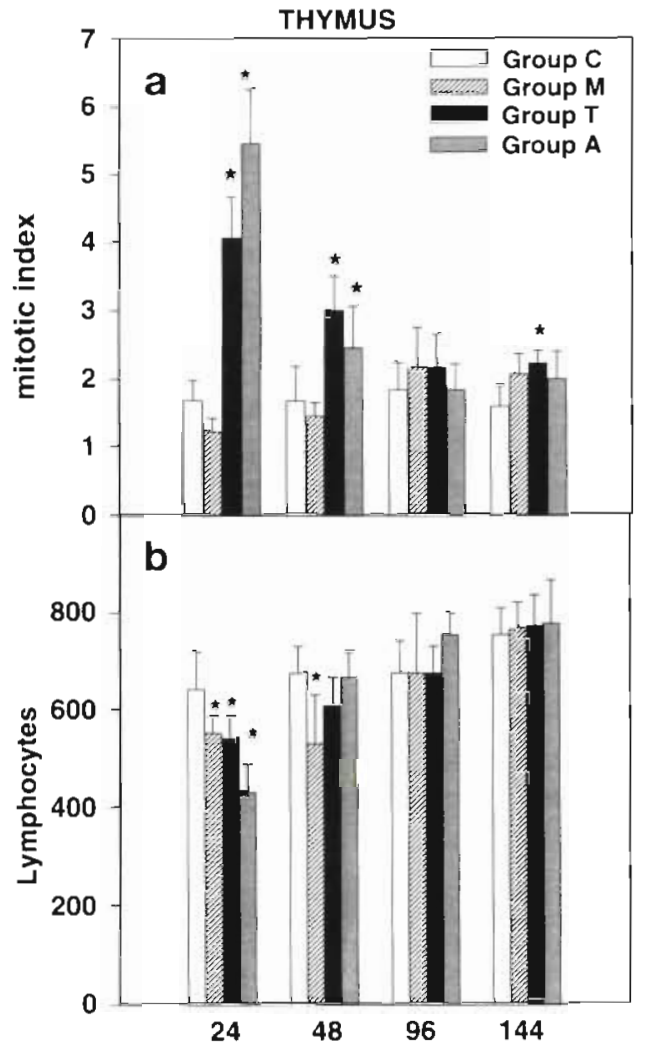

Fig. 1. Sparus aurata. Thymus response to the 3 treatments $24,48,96$ and $144 \mathrm{~h}$ after the beginning of the experiment. (a) Mitotic index (number of mitoses per $40000 \mu \mathrm{m}^{2}$ ). (b) Lymphocytes (number per $6400 \mu^{2}$ ). C: control group; $\mathrm{M}$ : group subject to handling; $T$ : group subject to handling plus confinement without anaesthetic; A: group subject to handling plus confinement with anaesthetic. Results are means $\pm \mathrm{SD}^{*}{ }^{\star} \mathrm{p}<$ 0.05 denotes the significant differences between treated and control fish at any given time

Table 1. Sparus aurata. Effect of handling, and handling plus confinement with and without an anaesthetic on circulating white blood colls. Cells were counted using a E11 A $-21 \mathrm{~mm} / 1 \mathrm{~mm}$ Index Grid (Graticules Ltd). Results are expressed as the mean \pm SD of percentage of each cell type. $\cdot p<0.05$ denotes significant differences between treated and control fish at any given time

\begin{tabular}{|c|c|c|c|c|c|}
\hline Variable & Group & $24 \mathrm{~h}$ & $48 \mathrm{~h}$ & $96 \mathrm{~h}$ & $144 \mathrm{~h}$ \\
\hline Heterophils & $\begin{array}{l}\text { Control (C) } \\
\text { Handled (M) } \\
\text { Confined (T) } \\
\text { Anaesthetized (A) }\end{array}$ & $\begin{array}{l}41.7 \pm 7.6 \\
55.8 \pm 9.3^{\circ} \\
53.3 \pm 6.1^{\circ} \\
41.8 \pm 12\end{array}$ & $\begin{array}{l}49.2 \pm 7.0 \\
70.0 \pm 5.4 \\
34.7 \pm 6.2^{*} \\
39.9 \pm 7.8\end{array}$ & $\begin{array}{l}62.1 \pm 14.0 \\
48.4 \pm 10.2^{*} \\
50.1 \pm 10.5 \\
47.2 \pm 9.8^{\circ}\end{array}$ & $\begin{array}{l}30.1 \pm 12.1 \\
34.9 \pm 7.8 \\
40.3 \pm 10.3 \\
37.3 \pm 10.1\end{array}$ \\
\hline Acidophils & $\begin{array}{l}\text { Control }(C) \\
\text { Handled }(M) \\
\text { Confined }(T) \\
\text { Anaesthetized (A) }\end{array}$ & $\begin{array}{l}13.0 \pm 5.9 \\
14.6 \pm 4.0 \\
24.4 \pm 3.4 \\
17.2 \pm 5.9\end{array}$ & $\begin{array}{r}9.1 \pm 2.2 \\
10.3 \pm 4.9^{\circ} \\
37.2 \pm 6.0^{\circ} \\
18.1 \pm 6.2^{\circ}\end{array}$ & $\begin{array}{l}9.2 \pm 7.2 \\
15.8 \pm 7.0 \\
21.0 \pm 10.4 \\
18.4 \pm 5.3\end{array}$ & $\begin{aligned} 12.4 & \pm 7.2 \\
19.2 & \pm 12.3 \\
11.0 & \pm 8.5 \\
6.8 & \pm 2.0^{\circ}\end{aligned}$ \\
\hline Basophils & $\begin{array}{l}\text { Control (C) } \\
\text { Handled (M) } \\
\text { Confined (T) } \\
\text { Anaesthetized (A) }\end{array}$ & $\begin{aligned} 12.5 & \pm 5.9 \\
4.6 & \pm 1.0 \\
5.4 & \pm 3.2 \\
11.6 & \pm 6.8\end{aligned}$ & $\begin{array}{r}8.0 \pm 1.5 \\
5.3 \pm 2.0 \\
11.2 \pm 4.8 \\
19.6 \pm 7.4\end{array}$ & $\begin{array}{r}9.0 \pm 5.0 \\
12.3 \pm 3.2 \\
13.0 \pm 5.5 \\
17.7 \pm 4.2\end{array}$ & $\begin{aligned} 8.2 & \pm 6.0 \\
12.0 & \pm 6.2 \\
16.3 & \pm 5.4 \\
12.1 & \pm 4.1\end{aligned}$ \\
\hline Lymphocytes & $\begin{array}{l}\text { Control (C) } \\
\text { Handled (M) } \\
\text { Confined (T) } \\
\text { Anaesthetized (A) }\end{array}$ & $\begin{array}{l}31.1 \pm 5.2 \\
31.1 \pm 12.3 \\
15.8 \pm 8.8^{*} \\
43.5 \pm 9.4\end{array}$ & $\begin{array}{l}23.5 \pm 4.7 \\
14.1 \pm 6.4^{*} \\
23.4 \pm 7.0^{*} \\
32.3 \pm 15.2\end{array}$ & $\begin{array}{l}17.0 \pm 2.9 \\
18.8 \pm 5.2 \\
14.7 \pm 4.1 \\
28.2 \pm 10.0\end{array}$ & $\begin{array}{l}29.4 \pm 8.2 \\
23.5 \pm 5.8 \\
19.4 \pm 9.4 \\
44.1 \pm 13.5\end{array}$ \\
\hline
\end{tabular}


most severe in the anaesthetized fish (Fig. 1), was no longer present at $48 \mathrm{~h}$ in both confined groups and at $96 \mathrm{~h}$ in the handled group.

\section{Spleen}

Handling caused an increase in the number of melanomacrophage centres (MMC) in the spleen by $24 \mathrm{~h}_{\text {; }}$ in contrast, handling plus confinement caused a decrease in MMC (Fig. 2). Importantly, the anaesthetic reversed the effect of handling plus confinement. Forty-eight hours after the onset of stress the number of $\mathrm{MMC}$ in the 3 stressed fish groups was significantly higher than in the control group (Fig. 2). The overall leucocyte number in the handled group was significantly higher at $24 \mathrm{~h}$ (Fig 2), and had increased in the 3 treatments at $48 \mathrm{~h}$. Complete recovery was observed at $96 h_{i}$ at this time significant lymphocytopenia in the confined plus anaesthetic fish was observed (data not shown).

\section{Head kidney}

Handling had only minor effects on immunological cells of this tissue (Fig. 3). Handling plus confinement

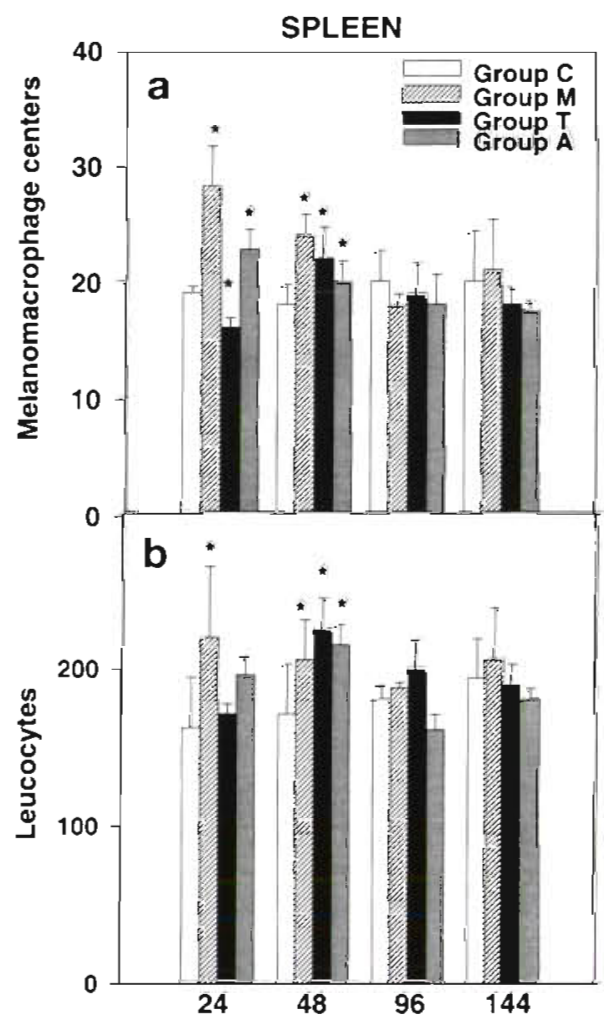

Fig. 2. Sparus aurata. Spleen response for the 4 treatments 24 , 48,96 and $144 \mathrm{~h}$ after the beginning of the experiment. (a) Melanomacrophage centres (number per $640000 \mu \mathrm{m}^{2}$ ). (b) Leucocytes (number per $6400 \mu^{2}$ ). (See Fig. 1 for more details)

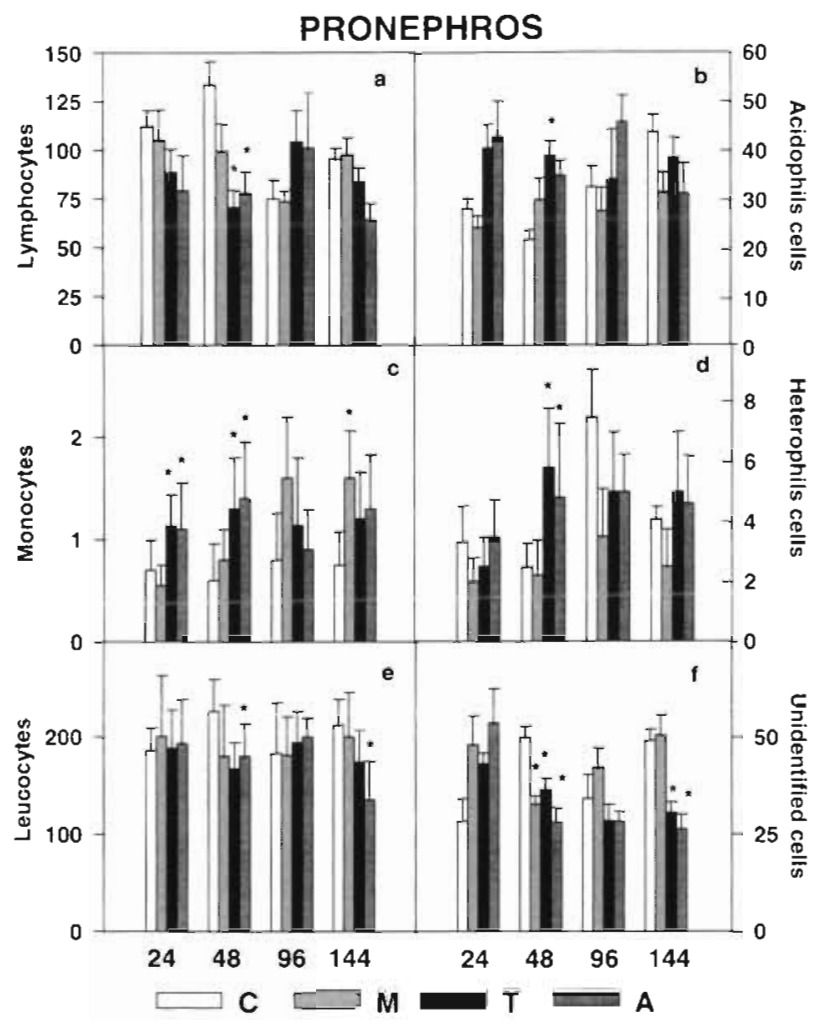

Fig. 3. Sparus aurata. Pronephros response for the 4 treatments $24,48,96$ and $144 \mathrm{~h}$ after the beginning of the experiment. Number per $6400 \mu^{2}$ of (a) lymphocytes, (b) acidophils, (c) monocytes, (d) heterophils, (e) leucocytes, (f) unidentified cells. (See Fig. 1 for more details)

had, in general, greater effects than handling alone; importantly, the pattern of the response for handling plus confinement was different than that for handling alone. For example, handling increased monocyte levels at 96 to $144 \mathrm{~h}$, whereas handling plus confinement increased them at 24 to $48 \mathrm{~h}$. The presence of an anaesthetic, in general, did not alter the response of the head kidney immunological cells to handling plus confinement.

\section{DISCUSSION}

Handling and handling plus confinement, a situation comparable to transport conditions in aquaculture, induce changes not only in circulating white blood cells but also in the thymus, spleen and pronephros in the gilthead sea bream. The expected changes induced by these 2 stressors were clearly observed (Pickering et al. 1982, Ellsaesser \& Clem 1986, Fletcher 1986, Bly et al, 1990, Ainsworth et al. 1991). In addition, the presence of an anaesthetic reversed or delayed most of the changes, suggesting that the 
anaesthetic plays a protective role. However, tissue response demonstrated that the most severe effect was produced by handling plus confinement with an anaesthetic. A strong lymphocytopenia was observed in the thymus and pronephros in fish subjected to this treatment, which could be explained by the fact that the number of lymphocytes in circulation is maintained. If only circulating lymphocytes were measured in order to determine immune status, a false conclusion could therefore result. The long-term response of the immune system could be more accurately evaluated by analyzing tissue response.

The thymic response to stress could be described as an initial involution or atrophy followed by a phase of thymic regeneration with increased mitotic activity, as shown by Chilmoncyzk (1992). These changes seem to indicate that confinement increases the overall thymic response including increases in the mitotic index. When fish were exposed to an anaesthetic, the thymic response lasted for more than $96 \mathrm{~h}$.

The pronephros showed the greatest and longest response to handling plus confinement with and without an anaesthetic. In fact, cellular changes in the pronephros could still be observed $144 \mathrm{~h}$ after the onset of stress. As Peters \& Schwarzer (1985) stated, the increase in the heterophil cell content in the pronephros during the first reaction phase to the stressor probably reveals a functional activation of the haemopoietic tissue. Rowley et al. (1988) reported that the granulocyte function is an important non-specific defense in fish. Fish heterophilic granulocytes have been described as active ameboid and phagocytic cells (Morrow \& Pulsford 1980, Hyder et al. 1983), which serve as a first line of cell-mediated defense (Ainsworth et al. 1991). The observed effect is likely caused by the activation of the pituitary-adrenal axis. Adrenocorticotrophic hormone (ACTH) and corticosteroids are normally released during stress in fish (Donaldson 1981, Mazeaud \& Mazeaud 1981, Pickering 1992). Roberts (1978) and Peters \& Schwarzer (1985) have shown that injection of $\mathrm{ACTH}$ and corticosteroids in teleosts causes cellular depopulation of the pronephros and spleen. Other authors have shown that treatment with steroids causes not only cell depletion in kidney, spleen and thymus, but also histologic lesions in the thymus (Chilmonczyk 1992). The significant decrease in the number of unidentified cells in the 3 treatments could be explained by cell differentiation in several leucocyte populations which takes place in order to provide specific cell defense.

Handling increases the percentage of macrophages in the spleen. In haematopoietic organs of fish, macrophages assemble in the MMCs, where phagocytosed material is degraded, removed or deposited (Agius 1985). The kinetics of MMC formation were discussed by Mori (1980) and Herraez \& Zapata (1986), who suggested that macrophages move to pre-existing aggregates or form new ones. Although MMCs are most commonly present in the spleen, pronephros, liver and gonads of fishes, they have never been reported in the thymus. Agius (1985) suggested that this may be due to a specialized vascular endothelium that protects this organ from haematogenous material. The occurrence of MMCs in the spleen and kidney of fish depends on several endogenous and exogenous factors. Increases in MMCs have been linked to immunization (Secombes et al. 1982), metabolic conditions (Roberts 1978) and stress (Blazer et al. 1987). If the stimuli required for the production of MMCs are cellular degradation products or foreign material, we could explain the increased MMC number in the handled group as a result of an increased catabolism due to the stress response. The increased MMC number in the A group (handled plus confined with the addition of an anaesthetic) would be due to both the stress response and to the presence of the anaesthetic as a foreign material. On the other hand, pituitary-adrenal-axis activation due to anaesthetic treatment has been previously demonstrated (Molinero \& Gonzalez 1995)

The significance of this work was the determination of the effect of stress resulting from handling and confinement procedures common in aquaculture. Circulating leucocyte counts, often used as a parameter to assess the immunological health of fish, have been shown here not to accurately reflect the real health status of the fish because circulating levels of leucocytes are maintained by the immunological organs. Other studies in our laboratory have shown that in gilthead sea bream differences in circulating lymphocyte numbers were noted between 3 and $9 \mathrm{~d}$ after acute or chronic disturbance (Suñer \& Tort 1995, Suñer et al. 1995, Tort et al. 1996).

In summary the health status of the fish after a single disturbance is only temporarily affected. However, if consecutive disturbances occur before full recovery of the immunological organs, a stronger immunodepression probably resulting in increased mortality rates is produced. The presence of an anaesthetic during transport does not modify the response of the organ. As a word of caution to those working with gilthead sea bream, fish should not be used or perturbed until at least $144 \mathrm{~h}(6 \mathrm{~d})$ after handling and transport, when cellular recovery in the immunological organs is complete. A specifity test to assess the immune response to pathogens after the immunological changes produced by handling and handling plus confinement stress would be very important to assess the effect of handling and handling plus confinement on disease susceptibility and survival. 
Acknowledgements. This work was supported by the project grants from the Commisio interdepartamental de reçerca i tecnologia of the Generatitat de Catalunya (AR91-109 and GRQ93-2096) and by a Grant Mar-90 (CICYT, Ministerio de Educación y Ciencia). We thank Juan Gonzalez and Marc Puigcerver for animal husdandry, blood collection and surgery. We are grateful to the Zoo de Barcelona for their technical assistance. We are indebted to Dr J. Hidalgo from our Department for helpful suggestions.

\section{LITERATURE CITED}

Agius C (1985) The melano-macrophage centres of fish: a review. In: Manning MJ, Tanner MF (eds) Fish immunology. Academic Press, London, p 85-105

Ainsworth AJ, Dexiang C, Waterstrat PR (1991) Changes in peripheral blood leukocyte percentages and function of neutrophils in stiessed channel catfish. J Aquat Anim Health 3:41-47

Anderson DB, Roberson BS, Dixon OW (1982) Immunosuppression induced by a corticosteroid or an alkylating agent in rainbow trout (Salmo gairdneri) administered a Yersinia ruckeri bacterin. Dev Comp Immunol 7 (Suppl 2):197-205

Blazer WS, Wolke RE, Brown J, Powel CA (1987) Piscine macrophage aggregate parameters as health monitors: effect of age, sex, relative weight, season and site quality in largemouth bass (Micropterus salmoides). Aquat Toxicol NY 10:199-215

Bly JE, Miller NW, Clem LW (1990) A monoclonal antibody specific for neutrophils in normal and stressed channel catfish. Dev Comp Immunol 14:201-221

Chilmonczyk S (1992) The thymus in fish: development and possible function in the immune responses. Ann Rev Fish Dis 2:181-200

Donaldson EM (1981) The pituitary-interrenal axis as an indicator of stress in fish. In: Pickering AD (ed) Stress and fish. Academic Press, New York, p 11-48

Ellsaesser CF, Clem LW (1986) Haematological and immunological changes in channel catfish stressed by handling and transport. J Fish Biol 28:511-521

Fletcher TC (1986) Modulation of nonspecific host defenses in fish. Vet Immunol Immunopathol 12:59-67

Herraez MP, Zapata A (1986) Structure and function of the melano-macrophage centres of the goldfish Carassius auratus. Vet Immunol Immunopathol 12:117-126

Hyder SL, Cayer ML, Pettey CL (1983) Cell types in peripheral blood of the nurse shark: and approach to structure and function. Tissue Cell 15:437-455

Maule AG, Schreck CB (1990) Changes in numbers of leucocytes in immune organs of juvenile coho salmon after acute stress of cortisol treatment. J Aquat Anim Health 2 298-304

Maule AG, Schreck CB, Kaatari SL (1987) Changes in the immune system of coho salmon Oncorhynchus kisutch during the parr-to-smolt transformation and after implantation of cortisol. Can J Fish Aquat Sci 44:161-166

Maule AG, Tripp RA, Kaatari SL, Schreck CB (1989) Stress alters immune functions and disease resistance in chinook salmon (Oncorhynchus tshawytscha). J Endocrinol 120: $135-142$

Mazeaud MM, Mazeaud F (1981) Adrenergic response to stress in fish. In: Pickering AD (ed) Stress and fish. Academic Press, New York, p 49-76

Molinero A, Gómez E, Balasch J, Tort L (1997) Stress by fish removal in the sea bream Sparus aurata. A time course study on the remaining fish in the same tank. J Appl Aquacult (in press)

Molinero A, Gonzalez J (1995) Comparative effects of MS 222 and 2-phenoxyethanol on gilthead sea bream (Sparus aurata L.) during confinement. Comp Biochem Physiol 111A3:405-414

Mori M (1980) Studies on the phagocytic system in goldfish I. Phagocytosis of intraperitoneally injected carbon particles. Fish Pathol 15:25-30

Morrow WJW, Pulsford A (1980) Identification of peripheral blood leucocytes of the dogfish (Sciliorhinus canicula) by electron microscopy. J Fish Biol 17:461-475

Peters G, Schwarzer R (1985) Changes in hemopoietic tissue of rainbow trout under influence of stress. Dis Aquat Org $1: 1-10$

Pickering AD (ed) (1981) Stress and fish. Academic Press New York

Pickering AD (1992) Rainbow trout husbandry: management of the stress response. Aquaculture 100:125-139

Pickering AD, Pottinger TG (1985) Cortisol can increase the susceptibility of brown trout Salmo trutta L. to disease without reducing the blood cell count. J Fish Biol 27:611-619

Pickering AD, Pottinger TC, Carragher JF (1989) Differences in the sensitivity of brown trout Salmo trout L. and rainbow trout Salmo gairdneri (Richardson) to physiological doses of cortisol. J Fish Biol 34:757-768

Pickering AD, Pottinger TG, Christie P (1982) Recovery of the brown trout Salmo trutta L., from acute handling stress: a time-course study. J Fish Biol 20:229-244

Roberts RJ (ed) (1978) Fish pathology. Bailliere Tindall, London

Rowley AF, Hunt TC, Page M, Mainwaring G (1988) Fish In: Rowley AF, Ratcliff NA (eds) Vertebrate blood cells. Cambridge University Press, Cambridge, p 19-127

Secombes CJ, Manning MJ, Ellis AE (1982) The effect of primary and secondary immunization on the lymphoid tissues of carp, Cyprinus carpio L. J Exp Zool 220:277-287

Slicher AM (1961) Endocrinological and hematological studies in Fundulus heteroclitus. Bull Bingham Oceanogr Collect Yale Univ 17:1-55

Suñer JO, Gómez E, Navarro V, Quesada J, Tort L (1995) Physiological responses and depression of humoral components of the immune system of gilthead sea bream (Sparus aurata) following daily acute stress. Can J Fish Aquat Sci 52:2339-2346

Suñer JO, Tort L (1995) Natural hemolytic and bactericidal activities of sea bream Sparus aurata are effected by the alternative complement pathway. Vet Immunol Immunopathol 45:333-345

Tort L, Gómez E, Montero D, Suñer JO (1996) Serum hemolytic and agglutinating activity as indicators of fish immunocompetence: their suitability in stress and dietary studies. Aquacult Inter 4:31-41

Wedemeyer GA (1970) Stress and anesthesia with MS 222 and benzocaine in rainbow trout (Salmo gairdneri). J Fish Res Bd Can 27:909-914

Wedemeyer GA, McLeay DJ (1981) Methods for determining the tolerance of fishes to environmental stressors. In: Pickering AD (ed) Stress and fish. Academic Press, New York, p $247-276$

Zuasti A, Ferrer C (1988) Granulopoiesis in the head kidney of Sparus aurata. Archives Histol Cytol 51:425-431

Zuasti A, Ferrer C (1989) Haemopoiesis in the head kidney of Sparus aurata. Archives Histol Cytol 52(3):249-255 